\title{
The Mystery of Louis Verrey (1854-1916)
}

Semir Zeki

"Le centre du sens chromatique se trouverait dans la partie la plus inférieure du lobe occipital, probablement dans la partie postérieure des plis lingual et fusiforme» ${ }^{1}$

L. Verrey, 1888

\section{SUMMARY}

In 1888, Louis Verrey, a Swiss ophthalmologist, stated emphatically that there is $a$ "centre for the chromatic sense" in the human brain and that it is located in the lingual and fusiform gyri. He did not, however, consider the "colour centre" to be a separate area but a large sub-division of the primary visual cortex. His evidence was quickly dismissed and forgotten. It was not to be taken seriously again until after the experimental discovery of functional specialization in the monkey brain. This paper considers why it is that Verrey did not consider the "colour centre" to be a separate cortical area, distinct from the primary visual cortex, why his evidence was so quickly and effectively dismissed, and why it is that Verrey did not pursue the logic of his findings.

Nothing about Louis Verrey's life or career suggests that he might have been the source of a revolutionary idea about the brain, one that was so far ahead of its time that even he missed its significance. It was perhaps his misfortune, as well as that of the subject, that everyone else missed the significance of his finding as well. He is not a household name in neurology. The few who refer to him at all usually give his initial as D., for no better reason than that his best known publication is "par le Dr. Verrey" and does not carry his initials. Yet that paper is no mean contribution to neurology. It confidently asserts that there is a separate colour centre in the brain. With equal confidence it gives the location of that centre. But there is no follow-up to the paper, no attempt to defend himself against those who believed that the notion of a colour centre in the brain was an absurdity, no hint that he saw the enormous consequences for understanding the functioning of the brain, no attempt to probe deeper into why there should be a separate colour 


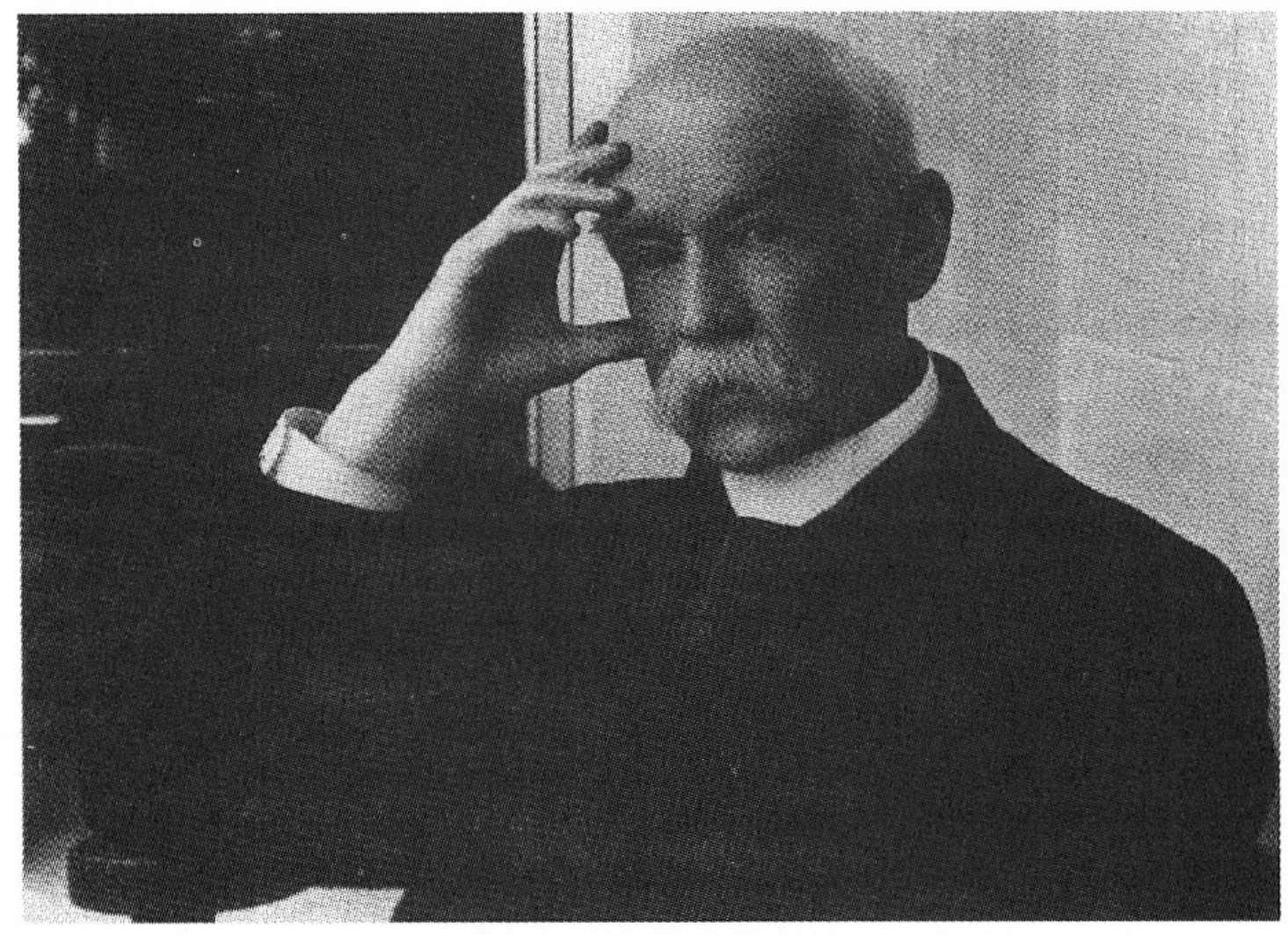

Portrait of Louis Verrey (1854-1916), courtesy of Dr. J.-D. Verrey, great grandson of Louis Verrey and, like him, an ophthalmologist practicing in Lausanne. This constitutes an uninterrupted line of ophthalmologists from Louis to the present day.

centre. The biographer of Verrey is thus faced with a triple puzzle. Why did Verrey have the confidence to write as he did, though never to defend his finding against its detractors? Why, having such confidence in his finding, did he not pursue its logic and enquire more deeply into its significance? And why was it apparently so easy for other neurologists to dismiss his findings and relegate them to oblivion?

A glance at his picture (Fig. 1) suggests immediately what he really was, a thoughtful and cultured man, one not lacking in confidence, indeed a pillar of Swiss society. Born into the high bourgeoisie of Switzerland, the son of an architect, he was a clinician by training, meticulous in his habits, outward looking, much interested in the affairs of his society and of the world, a caring parent and an accomplished musician. He was, above all, a man concerned with the welfare of his patients, to whom he gave his services freely. A hazy sketch ${ }^{2}$ is all that we have of his life. Born in 1854 at Melun 
into a family of architects, he terminated his secondary education in Lausanne in 1873 with a baccalauréat in science and mathematics. He was later to study medicine, first at Erlangen and then at Leipzig, where he obtained his medical degree in 1877 . He seems to have had an obsession with collecting medical certificates which would allow him to practice freely both in Switzerland and abroad. Thus, following a stay in Geneva (where he obtained a degree in medical sciences) and in Basel (where he obtained his state diploma of medicine in 1879), he spent eighteen months in London where he became a member of the Royal College of Surgeons of England. Anxious to be able to practice in France, he obtained the necessary qualifications (at Besançon). To the very end, Verrey used to make a weekly journey to Pontarlier to treat his French patients. But this obsession did not have pecuniary ends. On the contrary, alongside his private pratice, he gave his services freely in Lausanne where he was at first the assistant of the then eminent ophthalmologist, Marc Dufour, at the Asile des Aveugles. In 1887, he established himself in Neuchâtel where, amongst his patients, was the lady who had suffered from an hemiachromatopsia, and who was to bring him such fame as he has. It was in 1892 that he settled definitively in Lausanne where, at the Clinique de Bois-Cerf, he cared freely for hundreds of patients per year. It was also in the same year that he obtained the title of privat-docent from the University of Lausanne.

\section{Concepts of the cortical processes in vision in Verrey's time}

When Verrey published his paper in 1888 , the idea that there might be a colour centre in the brain had already been mooted, though never convincingly. To understand the resistance to his views and to understand, too, why he never pursued the logical consequence of his finding, it is necessary to consider briefly the then current views of vision as a process and of the role of the cerebral cortex in it. At that time and until the last decade ${ }^{3}$, neurologists and neurobiologists of vision had adopted, usually without even knowing it, a deeply philosophical idea about the brain. They had come to believe that vision involved two more or less independent processes. One was the somewhat passive process of "seeing". This involved, so they believed, the passive reception by the cerebral cortex of the visual "impressions" formed on the retina. The other, active, process involved a comparison of the "received visual impressions" with previous "impressions" of a similar kind, leading to 
the understanding of what was "seen". As well, they supposed that each process has a separate cortical locus. It is difficult to trace the precise origins of this doctrine. But it is obvious that it bears a strong resemblance to Immanuel Kant's belief in the two Faculties of Sensing and Understanding, the former being a passive, and the latter an active, process. Whatever the origins, the consequences were clear. Neurologists believed that they could not begin to study the second process, that of understanding what was seen, until they had studied the first process, that of seeing. The main effort therefore was to chart the limits and extent of the "seeing" cortex, the part of the cerebral cortex which receives the retinal "impressions" and study the manner in which the retina is connected to the cortex. This "seeing" cortex had to receive all the visual impressions which, neurologists of the day believed, consisted of the three separate sensations, of light, of form and of colour. Magitot and Hartmann wrote in their detailed review ${ }^{4}$ :

«La mise en action du processus visuel comporte trois groupes de sensations: sensation brute de lumière, discrimination des formes, sensation chromatique. Les récupérations fonctionnelles après cécité corticale due à une traumatisation cranienne, mettent en évidence ces différentes qualités de la sensation.»

The notion that, in neurological terms, colour could be regarded as a separate visual attribute, even though it was considered to be nothing more than a visual "impression", to be received by the same visual area as the other attributes of vision, derived from the common observation that, following lesions of the occipital cortex, colour could be more severely affected than other attributes of vision. Neurologists were conspicuously uninterested to enquire why this should be so. Much more impressive to them was the more common total blindness which resulted from occipital lesions, a condition in which all the attributes of vision were lost. Thus, Marie and Chatelin, the French neurologists, wrote ${ }^{5}$ :

«Il est, en effet, classique de considérer l'hémiachromatopsie comme résultant d'une lésion légère de la sphère visuelle ou des radiations.»

For over a century, the same trite explanation was given for this phenomenon, without any attempt to enquire more deeply into why this should be so. In 1926 Magitot and Hartmann wrote ${ }^{4}$ :

«La perception colorée est plus fragile encore que la perception des formes et un trouble, si léger soit-il, entraîne, lorsqu'il est décelable, une hémiachromatopsie totale ou partielle.»

In 1939, Monbrun asserted with similar confidence ${ }^{6}$ : 
«La vision des couleurs est absolument superposable à la vision des formes [...] dans la projection corticale de la rétine [...] L'hémiachromatopsie ne peut être réalisée que si la fonction de réception ou de conduction n'est pas supprimée, mais simplement légèrement atteinte.»

Gordon Holmes, whose originality as a worker and a thinker has been much over-rated, wrote in $1945^{7}$ :

"Mild lesions of the visual cortex which do not abolish perception of light frequently disturb colour vision; there is no evidence that [colour vision] is subserved by any other region of the brain [besides the visuo-sensory cortex]."

Even as late as 1960, Teuber and his colleagues reflected these vague views with confidence, and without any hint of doubt. They wrote ${ }^{8}$ :

"Seemingly selective impairment of one aspect of vision (e. g. color discrimination) reflects, we believe, a corresponding rank order in the vulnerability of different levels of function, in the presence of lesions in their common substrate."

Why should this be so? No one enquired. Or, if they did, they remained very quiet about it, presumably because they had no plausible explanation.

Now one begins to glimpse some of the originality of Verrey. He, together with a very small number of neurologists in Germany and England, at least put forward a neurological explanation for this bizarre syndrome, in which colour vision alone is lost or is at least much more severely compromised than other aspects of vision. Chief among them was Hermann Wilbrand, the German neurologist. He had supposed that there are three separate centres in the brain, each one dealing with one of the three attributes of vision ${ }^{9}$. He believed that all the optic nerve fibres entered the "light sense" centre first, where only the fibres concerned with the light sense ended. The fibres concerned with the form and colour sense passed on to the next, form, centre, where only the form fibres ended, leaving the colour fibres to terminate in the last, colour, centre. But he imagined that the three centres occupied three different layers of the same visual area, the primary visual receptive centre in the brain. He had also supposed, though without compelling evidence, that these different layers could be individually injured. This view was to be echoed much later by another German neurologist, Walter Poppelreuter, who thought that

"We have a plurality of different systems [in the calcarine or visual receptive cortex], which are affected by lesions in different ways and which can also remain functional in different ways, i.e. the defect shows itself as specific for different systems" ${ }^{10}$, 
and included colour as one of his systems, though his clinical evidence was not convincing. The most emphatic statement was made by Sir William Gowers, Professor of Medicine at University College London. He wrote ${ }^{11}$ :

"It is, on the whole, probable that all impressions go first to the region of the apex of the occipital lobe, since disease here causes absolute hemianopia, and that a special half-vision centre for colour lies in front of this."

But, like others, he had no direct evidence to support his claim and his conclusion was, as in a court of law, based on the balance of probabilities, being "on the whole probable".

Verrey had a distinct advantage. Not only had he studied his patient, but he had also been able to determine the site of the lesion post mortem. No wonder that his conclusions were more firm, based more on direct evidence and less on the balance of probabilities. At that time, Verrey was practising at Neuchâtel. His patient was an elderly lady of 60 , who had suffered a stroke. The consequence was

«un léger rétrécissement concentrique de $15^{\circ}$ à $20^{\circ}$ dans toutes les directions [avec] une hémiachromatopsie droite absolue et complète, c'est-à-dire que dans la moitié intégrale du champ visuel binoculaire la perception chromatique est abolie ...»1

Verrey proposed that the three centres which Wilbrand had spoken of did not occupy different layers of the primary visual receptive centre (as Wilbrand had imagined), but different geographical positions within a large primary receptive centre, a notion that found favour in some quarters as Fig. 2, reproduced from an article published in 1906, shows. Using the earlier case of Eperon ${ }^{12}$ as well as the results of his own studies, he wrote ${ }^{1}$ :

«Le centre du sens chromatique se trouverait dans la partie la plus inférieure du lobe occipital [...] Plus haut, et vers la partie supérieure du lobe occipital, se trouverait le centre de la perception lumineuse, et probablement entre les deux le centre pour la perception des formes, qui est celui qui, [...] après le centre du sens chromatique, avait le plus souffert.»

Thus Verrey's view was different from that of Wilbrand. It was a difference for which he paid dearly, because it brought him into direct conflict with the ideas of Henschen on the extent of the visual receptive cortex.

\section{Henschen's all-seeing "cortical retina"}

Henschen was a neuropathologist of some eminence and, like many eminent people, tolerated no opposition to his views. He had unravelled the connections between the eye and the brain and had shown them to be topographi- 
cally organised and restricted to the territory of the striate cortex, which he therefore proposed to call the "cortical retina". Lesions in the "cortical retina" had predictable effects. A large lesion would lead to an hemianopia. A small lesion would lead to a scotoma and the position of the scotoma was an excellent guide to the part of the striate cortex affected, since the connections between the eye and the brain were so topographical. It was as if part of the "photographic plate" in the cortex had been destroyed and therefore unable to "receive" the visual "impressions". The "cortical retina", and the nature of the connections between the eye and the brain, thus seemed to provide powerful evidence in favour of the philosophical view that there was a "seeing eye" in the cortex, one which received passively the visual image formed on the retina. Henschen's "cortical retina" did not include the lingual and fusiform gyri, regions which Verrey had suggested were critical for colour vision and were subdivisions of the primary visual receptive area as he, Verrey, had conceived of it. Thus in Verrey's formula-

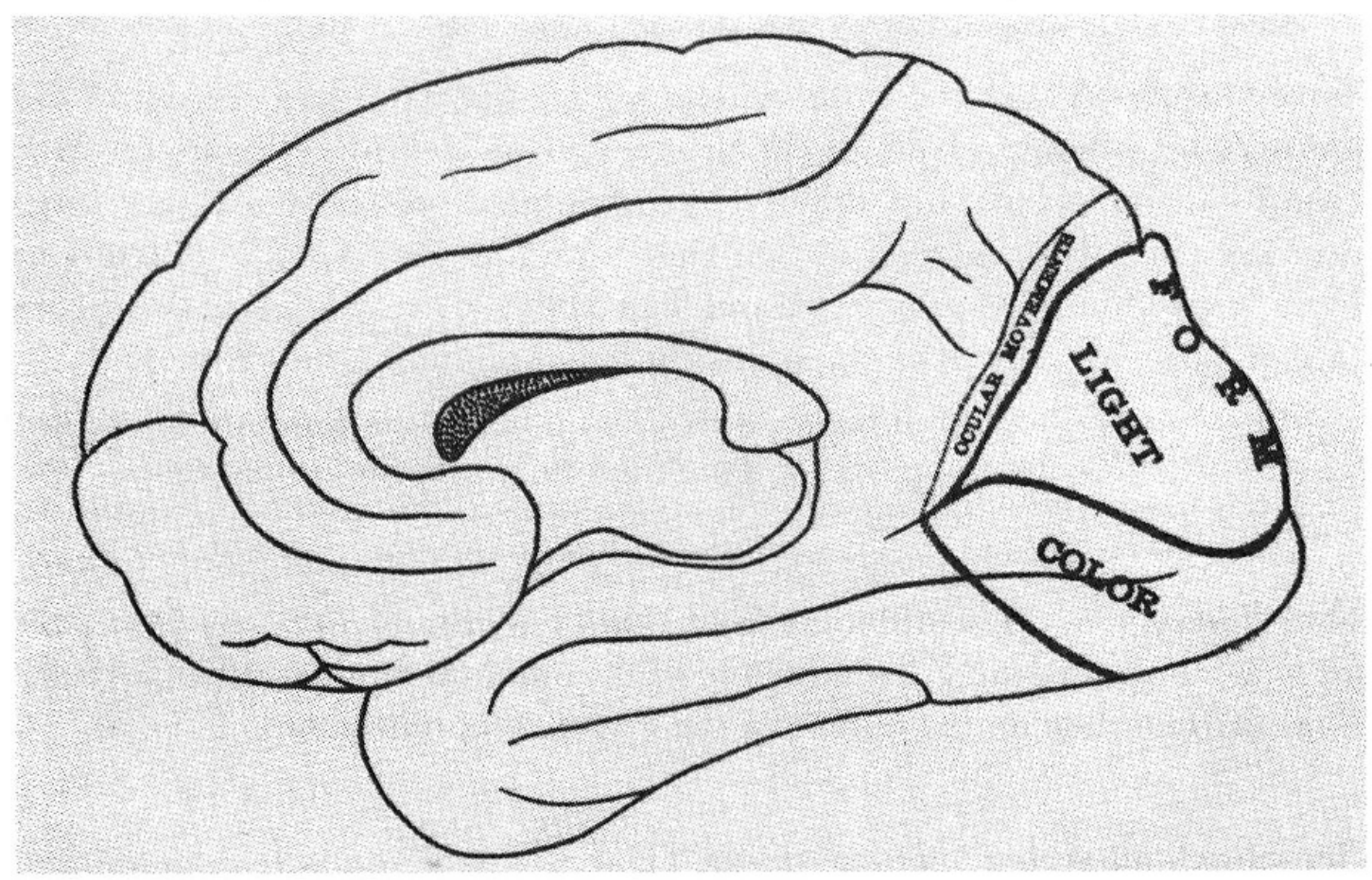

A contemporary diagram, published in 1906, of the subdivisions of the primary visual cortex subserving the different sub-modalities of vision, as they were then conceived. From Mill, C.K. (1906). The psychology of the visual act and the focal diseases of the visual cortex, In The Eye and the Nervous System, edited by W.C. Posey and W.G. Spiller, Lippincott, Philadelphia and London. 
tion, the primary visuo-sensory cortex was much larger than the area delineated by Henschen.

Henschen was impatient with the view of Verrey, and of others who had supposed that the primary visual cortex extends beyond the striate area. He wrote, by way of dismissing these other claims, including those of Verrey ${ }^{13}$ :

«La rétine cérébrale est en même temps une rétine pour les impressions des couleurs.»

In brief, his "cortical retina" was the cortex with which one also "saw" colour. The cortex outside the "cortical retina", and thus outside the striate area, had a different architecture, thus providing further support for the notion that it had a different function. That function might be visual but, if so, it was a visual function of much higher order, dealing with "understanding" what was seen. Henschen had drawn much comfort from the fact that Paul Flechsig, the brilliant professor of psychiatry at Leipzig, had described him as "the most careful worker in the field" ${ }^{14}$. Flechsig had found that one of the areas which was always myelinated at birth, and therefore a "primordial area", corresponded precisely with the "cortical retina" as defined by Henschen, i. e. with the striate cortex. By contrast, the areas surrounding the striate cortex, including the lingual and fusiform gyri, became myelinated much later, as if their myelination depended upon the acquisition of experience. This made them, so Flechsig supposed, "associational" areas, areas with higher psychic functions (Cogitationzentren). To Flechsig, the striate cortex was, therefore, the "entering place of the visual radiation into the organ of psyche", the areas around the visuo-sensory cortex becoming the "visuo-psychic" cortex ${ }^{14}$. Verrey's view that there was a colour centre, located in the lingual and fusiform gyri, and that this colour centre was a subdivision of the primary visual receptive centre, was not only in contradiction to the views of Flechsig; it also represented a threat to Henschen's doctrine that the cortex receiving the "visual impressions" is restricted to the striate cortex, for the fusiform and lingual gyri extended well beyond the striate cortex. How to deal with this critical impasses? The easiest was to dismiss it completely, by assertion. Henschen wrote that the "two cases of achromatopsia described by Verrier and Machay [sic] do not demonstrate, in my opinion, what these authors wanted to demonstrate" ${ }^{15}$. Verrey's supposition was, moreover, quite ridiculous for, if true, then a patient "in whom the striate cortex is destroyed and the cortex of that other gyrus [lingual and fusiform] is intact would have to be absolutely blind and yet be able to see colours, which makes no sense" ${ }^{16}$. 

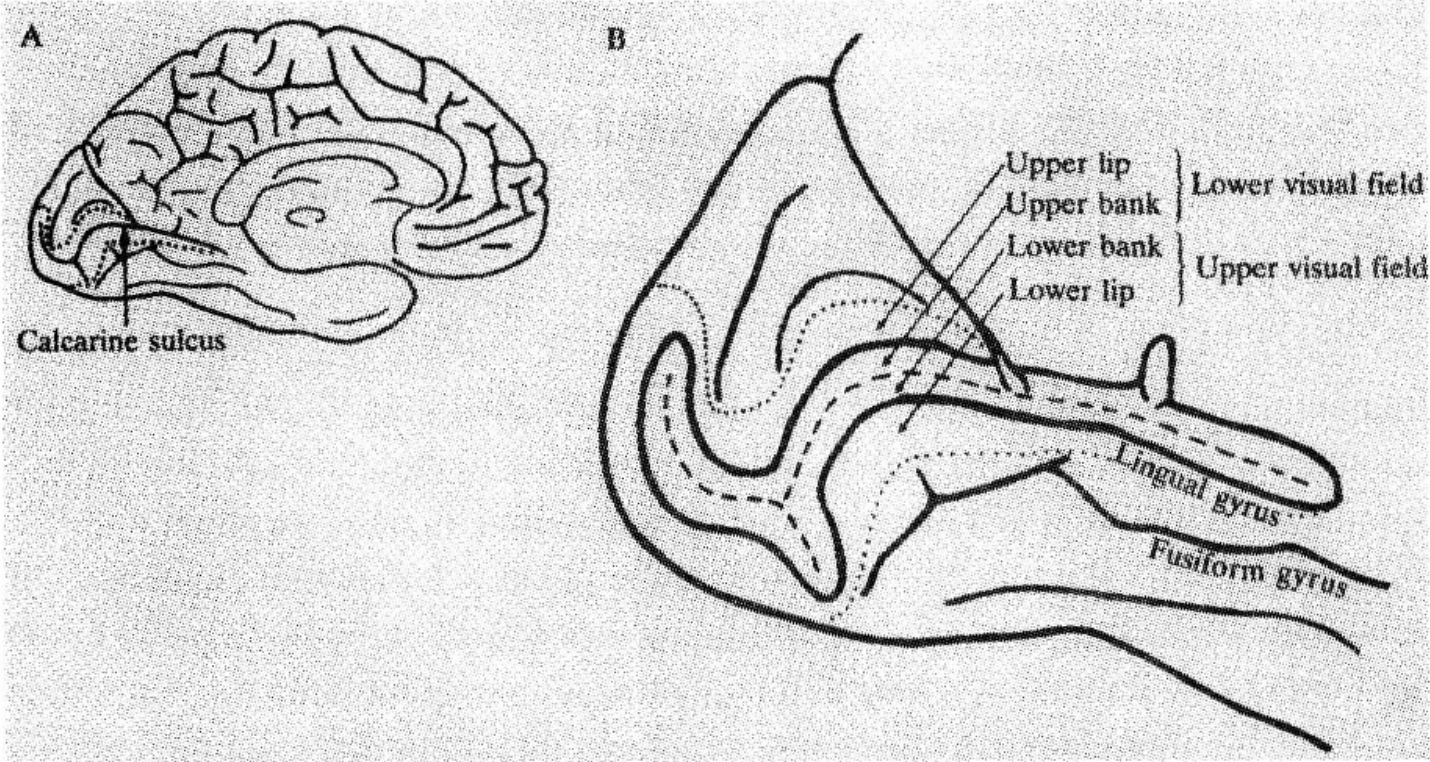

$A$ is a medial view of the brain to show the calcarine sulcus; $B$ is an enlargement of the posterior part of the brain to show the relationship of the calcarine sulcus to the lingual and fusiform gyri and the nature of retinal representation within the calcarine gyrus. Central vision is represented posteriorly, at the apex of the occipital lobe, while peripheral vision is represented anteriorly in the calcarine sulcus. Henschen thought that the opposite was true, a belief which led to much confusion. Because the fusiform gyrus, where the colour centre is situated, neighbours the inferior limb of the calcarine sulcus, achromathopsia is commonly accompanied by a blindness in the upper field of view, a relationship first pointed out by Meadows ${ }^{36}$.

There was, however, another point which must have irritated Henschen. It is contained in the critical line of Verrey's paper: "[...] dans la moitié intégrale du champ visuel binoculaire la perception chromatique est abolie». But this "moitié intégrale» included the central visual fields, and the total blindness (rétrécissement) had affected only the more peripheral fields. This was, at least in part, in contradiction to what Henschen had been preaching. For Henschen had supposed that central vision is represented anteriorly in the calcarine cortex and peripheral vision posteriorly, towards the occipital lobe (Fig. 3). That a lesion in the neighbourhood of the more anterior part of the calcarine sulcus should lead to a central visual defect was consistent with Henschen's view. But if Henschen's doctrine of how central and peripheral vision is mapped in the striate cortex were correct, then the consequence of a lesion involving the anterior part of the calcarine sulcus should have been an absolute scotoma in central, not peripheral, vision ${ }^{17}$. 


\section{The irrelevance of Verrey}

In fact, Verrey counted for nothing in Henschen's thoughts. Much more irritating to him was Constantine von Monakow, the "famous brain scientist" 18 who believed that not much was known about the visual cortex "in spite of the work of Henschen"19. Henschen despised him because von Monakow had supposed that the primary visual receiving cortex was much larger than the striate cortex, and therefore larger than the "cortical retina" as postulated by Henschen. Von Monakow had relied partly on anatomical studies, particularly those of Lannegrace ${ }^{20}$ in the monkey. Lannegrace had written:

«Les fibres optiques [...] s'irradient sur une étendue considérable de la convexité de l'écorce, depuis l'occiput en arrière jusqu'à la région motrice en avant; la majeure partie des fibres se concentrent dans le lobe occipital [...] La zone visuelle, zone de l'hémiopie, est donc très étendue; mais elle a son foyer principal dans l'occiput» [emphasis in the original].

But there was a more fundamental reason for von Monakow's view. He had come to believe that the brain was very plastic, that one part could take over the function of another. In the visual system, he saw a critical demonstration of this in the phenomenon of macular sparing, where macular (central) vision is spared after an extensive hemianopia resulting from damage to the occipital lobe. Von Monakow therefore developed the somewhat fantastic theory of a "mobile retinal centre". This supposed that the retina, and central vision in particular, is represented in many foci throughout the occipital lobe and that damage to one centre could be compensated for by the healthy functioning of another. It led von Monakow and his school to view Henschen's doctrine of a strict localisation, which they described as "une localisation à outrance» ${ }^{21}$, with much contempt. It was this theory of a mobile retinal centre which Henschen was to denounce, stating that it was "based on an assertion without proof. Science does not recognize assertions", and considering it much later to have been "disastrous for the development of the theory of visual function" 15 .

Here then was a view which supposed that the primary visual receiving cortex was much larger than that postulated by Henschen, and large enough to accommodate the lingual and fusiform gyri, where Verrey had located his colour centre, supposing it to be part of an extensive primary visual cortex. One might have thought that Verrey's evidence would have pleased von Monakow, that he might have used it to support his claim for a primary visual receptive centre going well beyond the territory demarcated by 
Henschen. As it happens, not only did he not use this evidence but, like Henschen, was actually totally hostile to Verrey and to the idea of a separate colour centre in the brain. Indeed, this hostility was the only thing that united Henschen and von Monakow, these two implacable enemies. Henschen's hostility is easy to account for: if Verrey's view were to be accepted, it would mean that the primary visual receptive cortex would not be limited to the calcarine cortex and would therefore be much larger than the area postulated by Henschen. He therefore used his assertive phrases to dismiss the evidence of Verrey and of others, writing that

"Some of my cases prove positively that colour perception is also situated in the calcarine cortex ${ }^{22}$."

For von Monakow to acknowledge that there might be a colour centre, a lesion of which would lead specifically to a permanent achromatopsia, would have been to acknowledge that the cortex was not so plastic after all, that one part of the cortex could not take over the function of another, as he had supposed. He wrote:

"Besides the one-sided cortical colour blindness, there was almost without exception some loss of visual acuity, limitation of visual fields and at times also word blindness (Verrey, Henschen). In any case, no case of totally isolated hemiachromatopsia supported by postmortem examination has yet been reported ${ }^{23}$."

In summary, the grounds on which the notion of a colour centre lying outside the striate cortex were dismissed actually had little to do with colour vision itself.

\section{Verrey reprints his paper}

If Verrey was aware of the views of Henschen and of von Monakow, he remained quiet about it. There is no attempt to reconcile the conflicting views or to discuss his finding in relation to them in the original article, published in 1888. His article was reprinted in $1893^{24}$, and this might have been the occasion to discuss alternative views or to discuss his findings in relation to the doctrines of Henschen and of von Monakow. But the reprint is identical to the original. Not only is there no discussion of these problems in either version, but there is a strong hint that Verrey himself was not even aware of the originality of his contribution and had supposed that it was nothing more than a confirmation of previous accounts. Quoting (inaccurately) Schneller ${ }^{25}$ he writes ${ }^{1}$ : 
«Enfin l'examen nécroscopique du cerveau a confirmé l'hypothèse généralement admise d'un centre cortical du sens chromatique, hypothèse qui a cependant été combattue par quelques auteurs.»

Perhaps because of this belief, perhaps because of the confidence he had in his results, or perhaps quite simply because he was a modest man, Verrey made little claim in his paper. He simply ended it thus ${ }^{1}$ :

«Tout ceci nous montre combien de questions sont à résoudre dans ce domaine des localisations cérébrales et combien nous nous mouvons encore sur un terrain peu ferme. Cependant, toute nouvelle contribution à cette étude a son importance pour l'édification de ce monument dont Charcot et ses élèves ont été les fondateurs et c'est là ce qui m'a engagé à publier l'observation précédente.»

Verrey may not have been alone in thinking that neurologists had agreed that there is a colour centre in the brain. In their review of 1929, Magitot and Hartmann ${ }^{4}$ write :

«Pendant longtemps, on a voulu localiser la vision chromatique dans un centre cortical particulier, à côté d'un centre distinct pour la vision lumineuse, et d'un autre pour la sensation des formes. Il a fallu cependant abandonner cette hypothèse, la perception colorée se superposant simplement aux autres modes de sensations visuelle [...] avec cette différence qu'elle se montre plus fragile.»

A review of the earlier literature ${ }^{3}$ does not suggest, however, that the concept of a colour centre in the cerebral cortex was "généralement admise». On the contrary, it was generally fiercely resisted when encountered. There are a few notable exceptions, but none seems to have made a deep impression on the neurological literature, assuming it to have made any impression at all. Wilbrand had entertained the notion of a colour centre, but had supposed that it resided in a separate layer of the primary visual cortex. In America, Brill ${ }^{26}$ had propounded a view not dissimilar to that of Verrey, supposing that two cortical fields abutting each other,

"of which limited lesion in one will produce hemianopia, and an extensive lesion of the other a slight general diminution in color".

But his patient had suffered not so much from achromatopsia as from a colour confusion syndrome and the lesion, in any case, included much of the calcarine cortex, the cuneus and the lingual gyrus as well. Others ${ }^{27}$ had entertained the notion of a colour centre, but none had the compelling evidence of Verrey, and indeed none had been as confident as Verrey in stating the precise location of the centre for the chromatic sense. After the publication of his paper, few took his results seriously, and the imperfect 
evidence for a colour centre in the human brain "vanished" ${ }^{28}$ from the clinical literature until the modern experimental evidence for specialized pathways and areas for colour vision was established in the monkey ${ }^{3}$.

How does one interpret the re-issue of Verrey's article in 1893, presumably with his knowledge and permission? It is unlikely that he would have agreed to the re-issue if he had developed doubts regarding the colour centre. He had had five years to consider the problem, five years during which doubts had been raised about the idea. It had been criticised by MacKay ${ }^{29}$, and had been strongly denounced by Henschen, among others. There is no evidence from the published record that Verrey himself ever sought to defend himself or his finding, or to rebut the contrary views of Henschen and of others. Yet the fact of re-publication suggests that he held to his views, and saw no reason to modify them. Perhaps he did not consider the topic to be of sufficient importance. This seems likely, given that his inaugural lecture at the University of Lausanne in $1892^{30}$ makes no mention of the topic; it discusses problems of optic development instead. Perhaps he was unaware of the criticism or, if aware of it, did not take it seriously. Perhaps, like any sensible person, he preferred his travels in Italy and France ${ }^{2}$ to the claustrophobic world of colour vision, usually inhabited by thoroughly disagreeable people. Who can blame him, and what sensible person wouldn't do the same? Whatever the real reason, there is little doubt that his silence was, in the long run, the best defence.

\section{A dialogue of the deaf}

To anyone surveying this debate from the distance of a century, the surprising aspect is twofold. On the one hand, there is the absence of the word and from the vocabulary of those debating the issue. Henschen was adamant that his cortical retina was also a retina for colour impression, and was dismissive of Verrey's claim. He never seems to have entertained the notion that the cortical retina and another centre in the cortex surrounding it might be critical for the perception of colours. Verrey never seems to have considered the notion that Henschen might be correct in his definition of the "cortical retina" but that another area, in the lingual and fusiform gyri, might also be critical for the perception of colours. In fact, our current evidence shows that Henschen's equation of the primary visual receptive cortex with the striate cortex was correct, as was his belief that the primary 
visual cortex is concerned with colour. Equally, our current physiological and anatomical evidence ${ }^{3}$ shows that there are at least two areas outside the striate cortex which are concerned with colour. In the monkey these are areas V 2 and V 4. Finally, the recent evidence from the human brain, using positron emission tomography, shows that there are at least two areas in the human brain which are concerned with colour, that one of them (area V 2) lies in the lingual gyrus and the other, $\mathrm{V} 4$, in the fusiform gyri ${ }^{31}$.

Had the early neurologists entertained the possibility that the striate cortex and an area outside it might be critical for colour vision, they might have gone yet further to enquire into the reasons for this. They might then even have come to the conclusion that colour vision is not, and cannot be, a simple visual "impression" as they had imagined. Is there any plausible reason why they might have considered such a notion, irrespective of what the clinical and pathological evidence had shown?

During the latter half of the last century, just before neurologists began to consider, and dismiss, the notion of a colour centre in the "association" cortex (fusiform gyrus), scientists of high position in the world of learning had considered the problem of colour vision in general terms. They had been impressed by the single most important property of the colour system, namely the ability of the organism to assign a constant colour to a surface in spite of wide-ranging fluctuations in the wavelength composition of the light in which the surface is viewed, a property that has acquired the title of colour constancy. In Germany, Hermann von Helmholtz wrote ${ }^{32}$ :

"By seeing objects of the same colour under these various illuminations, in spite of the difference of illumination, we learn to form a correct idea of the colour of bodies, that is to judge how such a body would look in white light; and since we are only interested in the colour that the body retains permanently, we are not conscious at all of the separate sensations which contribute to form our judgement [since the determination of colour is] not due to an act of sensation but to an act of judgement."

Ewald Hering also postulated higher cortical factors. He wrote ${ }^{33}$ :

"All objects that are already known to us through experience, or that we regard as familiar by their colour, we see through the spectacles of memory color, and on that account quite differently from the way we would otherwise see them."

In England, James Clerk Maxwell ${ }^{34}$ had spoken of colour vision as a "mental science". Experience, memory, attention-here was the stuff that neurologists had attached to the "association" cortex. Hence, had the neurologists debating the issue of a colour centre in association cortex considered the complexities of colour vision, they might have found it not at all implausible 
that a colour centre should be situated in association cortex, as they had conceived of it. But there is no evidence that the pronouncements of the scientists made the slightest impression on the neurologists. Indeed, in only two of the many documents which $I$ have consulted is there any allusion to the science of colour, and even there it is an allusion to classical colour theory in which Helmholtz comes out rather better than Hering ${ }^{35}$. It is equally true, however, that scientists interested in colour vision took not the slightest interest in clinical cases of acquired cerebral achromatopsia. The evidence from clinical neurology, especially as it relates to achromatopsia and dyschromatopsia, could have given them a great deal of interesting information, indeed could have supported the doctrines which supposed that colour vision involved much more than the mere reception by the cortex of the colour "impressions" formed on the retina. Assuming that scientists and neurologists exchanged views and talked to each other at all, it must surely have been a dialogue of the deaf.

In the last few years, our concept of the cortical processes involved in vision have changed a great deal ${ }^{3}$. The visual "association" cortex has been shown to be made up of a multiplicity of visual areas which undertake different tasks, among them colour vision. This has ushered in the concept of functional specialization in the visual cortex. It is in the context of this new doctrine that Verrey's findings have gained the acceptance which they never had previously. Yet it remains an extraordinary irony that it was the experimental evidence for functional specialization that gave credibility to the evidence of Verrey and to the syndrome of cerebral achromatopsia, which have lain buried for almost a century, rather than the syndrome of cerebral achromatopsia itself ushering in new ideas about the cerebral processes involved in vision. Verrey died from a heart attack in 1916, in a train on his way home. Perhaps there is symbolism in that death, too, for the journey of discovery about the operations of the visual cortex, a journey which the syndrome of cerebral achromatopsia is at the heart of, is far from being complete.

\section{Acknowledgement}

The idea of writing a brief piece about Louis Verrey was suggested to me by Jean Jacques Dreifuss. He collected much of the material from Swiss sources. I am very grateful for his encouragement and delighted with his collaboration. 


\section{References}

1 Verrey, [L.] (1881). "Hémiachromatopsie droite absolue», Archives d'Ophtalmologie (Paris), 289-301.

2 Dr. M. (1916). Gazette de Lausanne, 11 April 1916; Revue médicale de la Suisse romande (1916), 334-337; Dr. Taillens (1916), Schweizerische Rundschau für Medizin, 13, 260. British Medical Journal (1916), II, 639.

3 For a further and more detailed discussion, see Zeki, S. (1990), "A century of cerebral achromatopsia", Brain 113, 1721-1777 and Zeki, S. (1993) A Vision of the Brain, Blackwell, Oxford.

4 Magitot, A. and Hartmann, E. (1926). «La cécité corticale», Bulletin de la Société d'Ophtalmologie de Paris 38, 427-546.

5 Marie, P. and Chatelin, C. (1914-1915), «Les troubles visuels dûs aux lésions des voies optiques intracérébrales et de la sphère visuelle corticale dans les blessures du crâne par coup de feu», Revue Neurologique 22, 882-925.

6 Monbrun, A. (1939). Les affections des voies optiques rétrochiasmatique et de l'écorce visuel, in Traité d'Ophtalmologie, Société Française d'Ophtalmologie, Paris, Masson, pp. 903-905.

7 Holmes, G. (1945). "The Ferrier Lecture: The organization of the visual cortex in man", Proceedings of the Royal Society of London. B, 132, 348-361.

8 Teuber, H.-L. et al., (1960). Visual Field Defects after Penetrating Missile Wounds of the Brain, Harvard University Press, Cambridge, Mass.

9 Wilbrand, H. (1884). Ophthalmiatrische Beiträge zur Diagnostik der Gehirnkrankheiten, Wiesbaden, Bergmann.

10 Poppelreuter, W. (1923). «Zur Psychologie und Pathologie der optischen Wahrnehmung», Zeitschrift für die Gesamte Neurologie und Psychiatrie 83, 26-152.

11 Gowers, W. R. (1887). Lectures on the Diagnosis of Diseases of the Brain, Second edition, London. J. \& A. Churchill.

12 Eperon [S.] (1884). Hémiachromatopsie absolue, Archives d'Ophtalmologie (Paris) 4, $356-370$.

13 Henschen, S. E. (1894). Sur les centres optiques cérébraux, Revue Générale d'Ophtalmologie $13,337-352$.

14 Flechsig, P. (1905). Gehirnphysiologie und Willenstheorien, Fifth International Psychology Congress, translated by G. von Bonin (1960), pp. 73-89 in Some Papers on the Cerebral Cortex, Thomas, Springfield, Illinois.

15 Henschen, S. E. (1900). Sur le centre cortical de la vision, XIII ${ }^{e}$ Congrès International de Médecine, Paris, Ophtalmologie, 232-245.

16 Henschen, S.E. (1910). Zentrale Sehstörungen, pp. 891-918 in Handbuch der Neurologie, Volume 2, M. Lewandowsky (editor), Berlin, Springer.

17 In fact, von Monakow saw the contradiction in a similar case, that of MacKay and Dunlop (1899). "The cerebral lesions in a case of complete acquired colour-blindness", Scottish Medical and Surgical Journal, 5, 503-512. In addition to an achromatopsia, this patient had also developed a peripheral scotoma following an anteriorly placed lesion, in the fusiform gyrus. The patient impressed MacKay to such an extent that he forgot his earlier criticism of the syndrome of cerebral achromatopsia and his off-hand treatment of Verrey in a foot-note [MacKay, G. (1888). A discussion on a contribution to the study of hemianopsia, with special 
reference to acquired colour blindness, British Medical Journal, 2, 1033-1037]. MacKay and Dunlop were remarkably ungenerous to Verrey in their 1899 publication, believing their case "...to be the first complete case of the kind", whereas Verrey's "was one sided (only hemiachromatopsia) and showed a more extensive lesion of the cerebrum".

18 Henschen, S. E. (1930). Pathologie des Gehirns, Volume 8, Stockholm.

19 Monakow, C. von (1911). «Lokalisation der Hirnfunktionen», Journal für Psychologie und Neurologie, 17, 185-200. Translated by G. von Bonin (1960) in Some papers on the Cerebral Cortex, Thomas, Springfield, Illinois.

20 Lannegrace (1889). "Influence des lésions corticales sur la vue», Archives de Médecine Expérimentale et d'Anatomie Pathologique (Paris) 1, 289-324.

21 Vialet, M. (1894). Considérations sur le centre visuel cortical à propos de deux nouveaux cas d'hémianopsie corticale suivis d'autopsie, Archives d'Ophtalmologie (Paris) 14, 422-426.

22 Henschen, S. E. (1893). "On the visual path and centre", Brain 16, 170-180.

23 Monakow, C. von (1905). Gehirnpathologie, vol.4, Holder, Vienna.

24 Verrey [L.] (1893). Hémiachromatopsie droite absolue, Paris, Steinheil.

25 Verrey gives Schneller, Archiv für Ophthalmologie 23,79 as his reference to the dissenting view. In fact, the correct reference is Schneller (1882). «Zur Frage vom Farbensinncentrum», Archiv für Ophthalmologie 28, 73-92.

26 Brill, N. E. (1882). "A case of destructive lesion in the cuneus, accompanied by colorblindness", American Journal of Neurology and Psychiatry 1, 356-368.

27 Swanzy, H. R. (1883). "Case of hemiachromatopsia", Transactions of the Ophthamological Society of the United Kingdom 3, 185-189; Steffan (1881). «Beitrag zur Pathologie des Farbensinnes», Archiv für Ophthalmologie 27, 1-24.

28 Damasio, A. R. (1985). "Disorders of complex visual processing", pp. 259-288 in Principles of Behavioral Neurology, M.-Marsel Mesulam (editor), Philadelphia, Davis.

29 MacKay, G. (1888), loc. cit. (under 17).

30 Verrey, [L.] (1892). Introduction à un cours d'ophtalmologie (Leçon inaugurale faite le 4 mai 1892), Revue médicale de la Suisse romande 12, 665-685.

31 Zeki, S., Watson, J. D. G., Lueck, C. J., Friston, K. J., Kennard, C. and Frackowiak, R. S. J. (1991). "A direct demonstration of functional specialization in human visual cortex", Journal of Neuroscience 11, 641-649.

32 Helmholtz, H. von (1911). Handbuch der Physiologischen Optik, Volume 2, Hamburg, Voss.

33 Hering, E. (1960). Outlines of a Theory of the Light Sense, translated by L. Hurvich and D. Jameson, pp. 13-18, Cambridge, Harvard University Press.

34 Clerk, Maxwell J. (1872). "On colour vision", Proceedings of the Royal Institution of Great Britain, 6, 260-271.

35 Wilbrand, H. and Saenger (1904), Neurologie des Auges, Wiesbaden, Bergmann; Steffan (1881), «Beitrag zur Pathologie des Farbensinnes», Archiv für Ophthalmologie 27, 1-24.

36 Meadows, J. C. (1974). Disturbed perception of colours associated with localized cerebral lesions, Brain 97, 615-632.

Prof. Semir Zeki

Department of Anatomy

University College

Gower Street

London WC1E 6BT 